\title{
PENGARUH KOMPOSISI MEDIA HIDROPONIK TERHADAP PERTUMBUHAN TANAMAN TOMAT
}

\author{
Suhaedir Bachtiar ${ }^{1}$, Muhammad Rijal ${ }^{2}$, Dian Safitri ${ }^{3}$ \\ ${ }^{1}$ SMP Negeri 2 Batang, Jeneponto Sulawesi Selatan \\ ${ }^{2}$ Jurusan Pendidikan Biologi, Institut Agama Islam Negeri Ambon \\ ${ }^{3}$ Jurusan Pendidikan Biologi, Universitas Muhammadiyah Makassar \\ E-mail: subha3g@gmail.com
}

\begin{abstract}
Abstrak: Produksi tomat seringkali mengalami penurunan, yang dapat disebabkan oleh berbagai faktor antara lain kurangnya minat petani untuk membudidayakan tomat karena rendahnya hasil yang diperoleh. Faktor yang lainnya yang menyebabkan penurunan produksi yaitu perkembangan industri yang semakin maju dan pesat menyebabkan lahan pertanian semakin sempit. Tidak terdapat pengaruh komposisi media hidroponik (pasir, arang sekam dan serbuk gergaji) terhadap tinggi tanaman tomat. Namun terdapat pengaruh untuk diameter batang dan jumlah daun tanaman tomat. Dengan demikian, dapat dikatakan bahwa komposisi media hidroponik (pasir kali, arang sekam padi dan serbuk gergaji kayu jati) dapat mempengaruhi pertumbuhan tanaman tomat, dengan perlakuan terbaik berdasarkan hasil penelitian ini adalah 1:1:2 (1 kg untuk pasir kali: 1 kg untuk arang sekam padi: 2 kg untuk serbuk gergaji kayu jati)
\end{abstract}

\section{Kata Kunci: Hidroponik, Tomat, Pertumbuhan}

\section{THE MEDIA COMPOSITION HYDROPONICS ON THE GROWTH OF PLANTS TOMATOES}

\begin{abstract}
Tomato often has experienced a fall in production, that can be was caused by various factors of lack of interest among other farmers to cultivate tomatoes due to the low of the results obtained. Other factors that result in a decrease in the production of which is the more advanced industrial development and rapidly cause agricultural land are increasingly limited. There is no media the influence of composition hydroponic (sand, charcoal the husks, and sawdust) of high of tomato plants. But there were influence in order to diameter of the stem and number of leaves of tomato plants. Thus, it can be said that composition media hydroponics (sand times, charcoal chaff rice and sawdust teak) can affect the growth of plants tomatoes, with best treatment based on the research is 1: $1: 2$ ( $1 \mathrm{~kg}$ for sand times: $1 \mathrm{~kg}$ for charcoal a rice husk: $2 \mathrm{~kg}$ for sawdust teak)
\end{abstract}

Keywords: Hydroponik, Tomato, The Growth

BIOLOGI SEL (VOL 6 NO 1 EDISI JAN-JUN 2017 ISSN 2252-858X/E-ISSN 2541-1225) PAGE 52 
Peranan komoditi hortikultura cukup besar terhadap perbaikan gizi masyarakat, peningkatan pendapatan petani, perluasan kesempatan kerja, pengembangan agribisnis dan peningkatan ekspor. Salah satu jenis sayuran yang mempunyai nilai ekonomi dan prospek yang cerah adalah tanaman tomat. Tanaman tomat merupakan sayuran bergizi tinggi yang mempunyai banyak kegunaan untuk dikonsumsi. Buah tomat selain sebagai buah segar yang langsung dapat dimakan, dapat juga dijadikan sebagai bahan penyedap masakan dan bahan industri untuk dikonsumsi dalam bentuk olahan, misalnya untuk minuman sari buah tomat, jus tomat, saus tomat, sup dan bubur. Buah tomat juga dimanfaatkan untuk mencegah dan mengobati berbagai macam penyakit, seperti sariawan, beri-beri, radang syaraf, lemahnya otot-otot, dermatitis, bibir menjadi merah dan radang lidah (Cahyono, 1999).

Peningkatan jumlah penduduk, pendidikan, kesadaran gizi dan meningkatnya pendapatan masyarakat juga akan meningkatkan kebutuhan akan buah tomat. Secara statistik, potensi pasar buah tomat dapat dilihat dari hasil analisis Bank Dunia yang memprediksi peningkatan permintaan buah tomat rata-rata per tahun sekitar 3,6-4\% dalam periode 1988-2010. Menururt data yang ada pada Badan Pusat Statistik (BPS) Maluku tentang survei pertanian, produksi tanaman tomat di Maluku pada tahun 20102012 mengalami penurunan yang cukup besar. Pada tahun 2010 produksi tomat sebesar 1,43 ton, dengan produktivitas 362 ton/ha, dan tahun 2011 produksinya meningkat sebesar 2073 ton dengan produktivitas 5,48 ton/ha. Tahun 2012 sebesar 2135 ton dengan produktivitas 3,88 ton/ha (Badan Statistik, 2012).

Meningkatnya jumlah penduduk dan permintaan pasar terhadap berbagai jenis sayuran, dapat diusahakan dengan dilakukan budidaya secara hidroponik, yaitu budidaya dengan menggunakan berbagai jenis media tanam selain tanah serta menambahkan larutan hara ke dalam media tersebut. Diharapkan lahan yang sempit dapat menghasilkan produksi yang lebih tinggi, berkualitas, bersih dan dapat ditanam di semua musim.

Di Indonesia, hidroponik yang berkembang pertama kali yaitu hidroponik substrat. Hidroponik substrat merupakan sistem hidroponik yang mempergunakan media selain tanah seperti arang sekam, pasir, dan serbuk sabut kelapa yang steril. Teknik hidroponik ini sampai sekarang masih digunakan untuk mengusahakan sayuran dan buah yang bernilai jual tinggi. Hidroponik adalah cara bercocok tanam tanpa menggunakan tanah. Sebagai pengganti tanah dapat digunakan pasir arang, sekam dan serbuk gergaji. Arang sekam selain digunakan karena mudah didapat, ringan dan mempunyai porositas yang baik. Pasir tidak mudah menahan air tetapi sebagai media perakaran sangat baik, pasir mempunyai aerase yang baik untuk pertumbuhan akar tanaman sebab pasir mempunyai pori-pori makro lebih banyak dari pori-pori mikro. Serbuk gergaji adalah sisa hasil gergajian yang memiliki sifat menyimpan air yang baik (Wianta, 1993).

BIOLOGI SEL (YOL 6 NO 1 EDISI JAN-JUN 2017 ISSN 2252-858X/E-ISSN 2541-1225) PAGE 53 


\section{METODE PENELITIAN}

Jenis penelitian yang digunakan dalam penelitian ini adalah tipe penelitian deskriptif kuantitatif dengan pendekatan eksprimen lapangan guna melihat pengaruh komposisi media hidroponik (pasir, arang sekam dan serbuk gergaji) terhadap pertumbuhan tanaman tomat. Variabel X: Komposisi media hidroponik (pasir, arang sekam dan serbuk gergaji), dan Variabel Y: Pertumbuhan tanaman tomat meliputi: tinggi tanaman, jumlah daun, dan diameter batang. Penelitian ini dilaksanakan dalam bentuk Rancangan Acak Kelompok (RAK) dengan perlakuan berbagai komposisi media hidroponik sebagai berikut:

$\mathrm{H} 0=1: 1: 1(1 \mathrm{~kg}$ pasir $: 1 \mathrm{~kg}$ arang sekam $: 1 \mathrm{~kg}$ serbuk gergaji $)$

$\mathrm{H} 1=2: 1: 1(2 \mathrm{~kg}$ pasir $: 1 \mathrm{~kg}$ arang sekam $: 1 \mathrm{~kg}$ serbuk gergaji)

$\mathrm{H} 2=1: 2: 1(1 \mathrm{~kg}$ pasir $: 2 \mathrm{~kg}$ arang sekam $: 1 \mathrm{~kg}$ serbuk gergaji)

$\mathrm{H} 3=1: 1: 2(1 \mathrm{~kg}$ pasir $: 1 \mathrm{~kg}$ arang sekam $: 2 \mathrm{~kg}$ serbuk gergaji $)$

Prosedur pelaksanaan penelitian adalah sebagai berikut:

1. Persiapan Benih: Benih tomat sebelum disemai direndam terlebih dahulu dalam air hangat selama satu jam kemudian benih yang tenggelam dikecambahkan dalam baki semai yang berisi media tanah. Setelah bibit berumur 14 hari dipersemaian kemudian bibit dipindahkan ke polybag perlakuan yang berisi berbagai komposisi campuran media pasir, arang sekam dan serbuk gergaji sesuai perlakuan.

2. Persiapan Media Tanam: Media tanam hidroponik berupa pasir, arang sekam, dan serbuk gergaji di sterilkan. Berat masing-masing media adalah $4 \mathrm{~kg} /$ polybag sesuai dengan komposisi perlakuan. Masing-masing media (perlakuan) tersebut dimasukkan ke dalam polybag ukuran $(20 \mathrm{~cm}$ x $30 \mathrm{~cm}) \mathrm{cm}$. Setelah itu diletakkan sesuai dengan tata letaknya di lapangan.

3. Penanaman: Bibit yang telah berumur dua minggu atau 14 hari setelah semai atau berdaun 2-3 helai, dipindahkan ke kantong polybag perlakuan yang berisi media yang sesuai perlakuan. Bibit yang akan ditanam dipilih yang sehat dan berukuran seragam.

4. Pemeliharaan: Pemeliharaan meliputi penyiraman dan pemupukan, pemangkasan, pengairan, pengendalian hama dan penyakit. Penyiraman dimulai pada saat tanam dan dilakukan setiap hari, selanjutnya pada umur satu minggu setelah penanaman dilakukan pemupukan Gandasil D dengan dosis $1 \mathrm{gr} / 1$ air yang diberikan dengan volume pemberian $200 \mathrm{ml} /$ polybag. Pemberian pupuk Gandasil dilakukan dengan interval waktu selama 3 minggu hingga menjelang berakhirnya penelitian. Penyiraman dan pemupukan dilakukan secara manual ke masing-masing tanaman.

5. Pengamatan: Pengamatan dilakukan pada akhir penelitian yaitu umur 25 hari setelah tanam (HST). Adapun parameter pengamatan yang diamati dalam penelitian ini adalah:

a. Tinggi tanaman $(\mathrm{cm})$, diukur dari permukaan tanah sampai titik tumbuh tanaman yang dilakukan pada akhir penelitian. 
b. Diameter batang $(\mathrm{cm})$, diukur dengan menggunakan jangka sorong pada pangkal akar di atas permukaan tanah dan dilakukan pada akhir penelitian.

c. Jumlah daun (helai), dihitung jumlah daun yang telah membuka sempurna dan dilakukan pada akhir penelitian.

Untuk mengetahui adanya pengaruh yang signifikan dari data hasil penelitian yang diperoleh dari penelitian akan dianalisis data dengan menggunakan uji F (ANOVA) pada taraf signifikan 5\%. Apabila pada ANOVA menunjukan perbedaan yang signifikan pada taraf 5\%, maka dilakukan uji lanjutan dengan menggunakan uji Beda Nyata Terkecil (BNT) dengan taraf signifikan 5\% untuk mengetahui derajat beda antara perlakuan (Kemas. A. H, 2010).

\section{HASIL DAN PEMBAHASAN}

Berdasarkan hasil penelitian pengaruh tiga komposisi jenis media hidroponik terhadap pertumbuhan tanaman tomat, maka diperoleh hasil penelitian sebagai berikut:

1. Tinggi Tanaman

Hasil penelitian tinggi tanaman tomat pada tiga komposisi media hidroponik disajikan pada tabel berikut:

Tabel 1. Tinggi tanaman tomat $(\mathrm{cm})$

\begin{tabular}{|l|l|l|l|l|l|}
\hline \multirow{2}{*}{ Perlakuan } & \multicolumn{3}{l|}{ Kelompok } & \multirow{2}{*}{ T o t a l } & \multirow{2}{*}{ Rata-rata } \\
\cline { 2 - 6 } & I & II & III & & \\
\hline H0 & 22 & 17 & 22 & 61 & 20.33 \\
\hline H1 & 19 & 19 & 17 & 55 & 18,33 \\
\hline H2 & 17 & 15 & 15 & 47 & 15,67 \\
\hline H3 & 15 & 16 & 18 & 49 & 16,33 \\
\hline & & & & & $\mathbf{1 7 , 7 6}$ \\
\hline
\end{tabular}

Analisis varians tinggi tanaman tomat pada tiga komposisi media hidroponik disajikan pada tabel berikut:

Tabel 2. Sidik Ragam tinggi tanaman tomat

\begin{tabular}{|l|l|l|l|l|l|}
\hline SK & Db & JK & KT & F Hitung $^{\text {F }}$ & Fabel $_{\text {5\% }}$ \\
\hline Kelompok & 2 & 5,17 & 2,58 & $0,72^{\text {tn }}$ & 5,14 \\
\hline Perlakuan & 3 & 40 & 13,33 & $3,72^{\text {tn }}$ & 4,76 \\
\hline Galat & 6 & 21,5 & 3,58 & & \\
\cline { 1 - 3 } Total & 11 & 66,67 & & & \\
\hline
\end{tabular}

Ket $:$ tn $=$ Tidak nyata $\left(\mathrm{F}_{\text {Hitung }}<\mathrm{F}_{\text {Tabel }} 5 \%\right)$

Hasil perhitungan sidik ragam pada parameter tinggi tanaman menunjukan bahwa nilai $\mathrm{F}_{\text {Hitung }}$ perlakuan $(3,72)<\mathrm{F}_{\text {Tabel }}(4,76)$ pada taraf signifikan 5\%. Dengan demikian, dapat disimpulkan bahwa tiga komposisi jenis media hidroponik yang digunakan dalam penelitian ini tidak memberikan pengaruh yang nyata terhadap tinggi tanaman tomat.

2. Diameter Batang

Hasil penelitian diameter batang tanaman tomat pada tiga komposisi media hidroponik disajikan pada tabulasi data berikut:

BIOLOGI SEL (YOL 6 NO 1 EDISI JAN-JUN 2017 ISSN 2252-858X/E-ISSN 2541-1225) PAGE 55 
Tabel 3. Diameter batang tanaman tomat $(\mathrm{cm})$

\begin{tabular}{|l|l|l|l|l|l|}
\hline \multirow{2}{*}{ Perlakuan } & \multicolumn{2}{l}{ Kelompok } & \multirow{2}{*}{ T o t a l } & \multirow{2}{*}{ Rata-rata } \\
\cline { 2 - 4 } & I & II & III & & \\
\hline H0 & 3,29 & 7,86 & 12,18 & $\mathbf{2 3 , 3 3}$ & $\mathbf{7 , 7 8}$ \\
\hline H1 & 4,03 & 7,36 & 11,31 & $\mathbf{2 2 , 7}$ & $\mathbf{7 , 5 7}$ \\
\hline H2 & 3,96 & 6,67 & 10,81 & $\mathbf{2 1 , 4 4}$ & $\mathbf{7 , 1 5}$ \\
\hline H3 & 5,22 & 9,43 & 14,66 & $\mathbf{2 9 , 3 1}$ & $\mathbf{9 , 7 7}$ \\
\hline & & & & & $\mathbf{3 2 , 2 6}$ \\
\hline
\end{tabular}

Analisis varians diameter batang tanaman tomat pada tiga komposisi media hidroponik disajikan pada tabel berikut:

Tabel 4. Sidik Ragam diameter batang tanaman tomat

\begin{tabular}{|l|l|l|l|l|l|}
\hline SK & Db & JK & KT & FHitung & F Tabel 5\% \\
\hline Kelompok & 2 & 132,04 & 66,02 & $153,28^{*}$ & 5,14 \\
\hline Perlakuan & 3 & 12,24 & 4,08 & $9,48^{*}$ & 4,76 \\
\hline Galat & 6 & 2,58 & 0,43 & & \\
\cline { 1 - 3 } Total & 11 & 140,55 & & & \\
\hline
\end{tabular}

Keterangan: ${ }^{*}=$ Berbeda nyata $\left(\mathrm{F}_{\text {Hitung }}>\mathrm{F}_{\text {Tabel }} 5 \%\right)$

Untuk perhitungan sidik ragam diperoleh nilai $\mathrm{F}_{\text {Hitung }}$ perlakuan $(9,48)>\mathrm{F}_{\text {Tabel }}$ $(4,76)$ pada taraf signifikan 5\%. Artinya, tiga komposisi jenis media hidroponik yang digunakan dalam penelitian ini memberikan pengaruh yang nyata terhadap diameter batang tanaman tomat. Besarnya pengaruh tiga komposisi jenis media hidroponik terhadap diameter batang tanaman tomat berdasarkan koefisien keragaman adalah sebesar 2\%. Dan untuk mengetahui pengaruh perlakuannya adalah pada tabel berikut:

Tabel 5. Pengaruh Perlakuan untuk Diameter Batang Tanaman Tomat (cm)

\begin{tabular}{|l|l|}
\hline Perlakuan & Rata-rata \\
\hline H0 & $7,78 \mathrm{abc}$ \\
\hline H1 & $7,57 \mathrm{ab}$ \\
\hline H2 & $7,15 \mathrm{a}$ \\
\hline H3 & $9,77 \mathrm{~d}$ \\
\hline BNT 5\% & $\mathbf{1 , 3 1}$ \\
\hline
\end{tabular}

Keterangan: Perlakuan yang diikuti huruf yang sama berarti tidak berbeda nyata menurut BNT 5\%.

Dari hasil pengujian di atas, perlakuan $\mathrm{H} 3$ berbeda nyata dengan perlakuan lainnya, dan juga merupakan perlakuan terbaik karena nilai rata-ratanya yang paling tinggi dari nilai rata-rata perlakuan lainnya, yakni 9,77. Komposisi perlakuan $\mathrm{H} 3$ adalah 1:1:2 (1 kg pasir : $1 \mathrm{~kg}$ arang sekam : $2 \mathrm{~kg}$ serbuk gergaji).

3. Jumlah Daun

Hasil penelitian jumlah daun tanaman tomat pada tiga komposisi media hidroponik disajikan pada tabulasi data berikut:

Tabel 6. Jumlah daun tanaman tomat

\begin{tabular}{|l|l|l|l|l|l|}
\hline \multirow{2}{*}{ Perlakuan } & \multicolumn{2}{|l|}{ Kelompok } & \multirow{2}{*}{ T o t a l } & \multirow{2}{*}{ Rata-rata } \\
\cline { 2 - 6 } & I & II & III & & \\
\hline H0 & 9 & 9 & 11 & $\mathbf{2 9}$ & $\mathbf{9 , 6 7}$ \\
\hline
\end{tabular}

BIOLOGI SEL (YOL 6 NO 1 EDISI JAN-JUN 2017 ISSN 2252-858X/E-ISSN 2541-1225) PAGE 56 


\begin{tabular}{|l|l|l|l|l|l|}
\hline H1 & 12 & 15 & 19 & $\mathbf{4 6}$ & $\mathbf{1 5 , 3 3}$ \\
\hline H2 & 15 & 19 & 21 & $\mathbf{5 5}$ & $\mathbf{1 8 , 3 3}$ \\
\hline H3 & 17 & 21 & 25 & $\mathbf{6 3}$ & $\mathbf{2 1}$ \\
\hline & & & & & $\mathbf{6 4 , 3 3}$ \\
\hline
\end{tabular}

Analisis varians untuk jumlah daun tanaman tomat pada tiga komposisi media hidroponik disajikan pada tabel berikut:

Tabel 7. Sidik Ragam jumlah daun tanaman tomat

\begin{tabular}{|l|l|l|l|l|l|}
\hline SK & Db & JK & KT & FHitung $^{\text {F }}$ & Fabel 5\% \\
\hline Kelompok & 2 & 66,17 & 33,08 & $16,77^{*}$ & 5,14 \\
\hline Perlakuan & 3 & 212,92 & 70,97 & $35,98^{*}$ & 4,76 \\
\hline Galat & 6 & 11,83 & 1,97 & & \\
\cline { 1 - 3 } Total & 11 & 290,92 & & & \\
\hline
\end{tabular}

Keterangan: ${ }^{*}=$ Berbeda nyata $\left(\mathrm{F}_{\text {Hitung }}>\mathrm{F}_{\text {Tabel }} 5 \%\right)$

Analisis sidik ragam untuk jumlah daun tanaman tomat menunjukan bahwa pada taraf signifikan 5\% nilai $\mathrm{F}_{\text {Hitung }}$ perlakuan $(35,98)>\mathrm{F}_{\text {Tabel }}(4,76)$. Artinya, ada pengaruh penggunaan tiga komposisi jenis media hidroponik terhadap jumlah daun tanaman tomat. Besarnya pengaruh tiga komposisi jenis media hidroponik terhadap jumlah daun tanaman tomat berdasarkan koefisien keragaman adalah sebesar 2,1\%. Dan untuk mengetahui pengaruh perlakuannya dapat dilihat pada tabel berikut:

Tabel 8. Pengaruh Perlakuan untuk Jumlah Daun Tanaman Tomat (helai)

\begin{tabular}{|l|l|}
\hline Perlakuan & Rata-rata \\
\hline H0 & $9,67 \mathrm{a}$ \\
\hline H1 & $15,33 \mathrm{~b}$ \\
\hline H2 & $18,33 \mathrm{c}$ \\
\hline H3 & $21 \mathrm{c}$ \\
\hline BNT 5\% & $\mathbf{2 , 8 0}$ \\
\hline
\end{tabular}

Keterangan: Perlakuan yang diikuti huruf yang sama berarti tidak berbeda nyata menurut BNT 5\%.

Dari hasil pengujian di atas, perlakuan $\mathrm{H} 2$ dan $\mathrm{H} 3$ sama-sama tidak berbeda nyata. Keduanya berbeda nyata dengan perlakuan lainnya. Sedangkan untuk perlakuan terbaik terdapat pada perlakuan $\mathrm{H} 3$ karena nilai rata-ratanya yang paling tinggi dari nilai rata-rata perlakuan lainnya, yakni 21. Komposisi perlakuan $\mathrm{H} 3$ adalah 1:1:2 (1 kg pasir: $1 \mathrm{~kg}$ arang sekam : $2 \mathrm{~kg}$ serbuk gergaji).

Berdasarkan hasil penelitian dan analisis sidik ragam ditemukan bahwa, tidak terdapat pengaruh komposisi media hidroponik (pasir kali, arang sekam padi dan serbuk gergaji kayu jati) terhadap tinggi tanaman tomat yang ditunjukkan dengan nilai $\mathrm{F}$ hitung perlakuan $(3,72)<\mathrm{F}$ tabel $(4,76)$ pada taraf signifikan $5 \%$. Dengan demikian tidak terdapat pengaruh komposisi media hidroponik (pasir kali, arang sekam padi dan serbuk gergaji kayu jati) terhadap tinggi tanaman tomat.

Hasil penelitian untuk diameter batang tanaman tomat berdasarkan analisis sidik ragam memberikan pengaruh yang signifikan karena nilai $\mathrm{F}$ hitung perlakuan $>\mathrm{F}$ tabel yaitu 9,48 > 4,76 yang berarti ada pengaruh komposisi media hidroponik (pasir, arang 
sekam dan serbuk gergaji) terhadap pertumbuhan tanaman tomat. Besarnya pengaruh tersebut berdasarkan koefisien keragaman adalah $2 \%$. Sedangkan hasil penelitian untuk jumlah daun tanaman tomat berdasarkan analisis sidik ragam memberikan pengaruh yang signifikan karena nilai $F$ hitung perlakuan $(35,98)>\mathrm{F}_{\text {Tabel }}(4,76)$ pada taraf signifikan $5 \%$, yang berarti ada pengaruh penggunaan media hidroponik (pasir, arang sekam dan serbuk gergaji) terhadap jumlah daun tanaman tomat. Berdasarkan koefisien keragaman, besarnya pengaruh tersebut adalah $2,1 \%$

Pengaruh komposisi media hidroponik (pasir, arang sekam dan serbuk gergaji) terhadap diameter batang dan jumlah daun tanaman tomat disebabkan oleh kandungan unsur hara mikro. Umumnya tanaman sering kekurangan unsur hara mikro bila hanya mengandalkan pupuk akar yang mayoritas berisi hara mikro. Tanaman tomat dapat ditanam di segala jenis tanah, mulai tanah pasir sampai tanah lempung. Akan tetapi tanah yang ideal adalah tanah lempung berpasir yang subur, gembur, banyak mengandung bahan organik serta unsur hara dan mudah merembeskan air. Tanah yang selalu tergenang air menyebabkan tanaman menjadi kerdil dan mati (Pracaya, 1998).

Secara deskriptif, komposisi media hidroponik (pasir kali, arang sekam padi dan serbuk gergaji kayu jati) yang baik untuk pertumbuhan vegetatif tanaman tomat terdapat pada perlakuan H3 (1 kg pasir kali: $1 \mathrm{~kg}$ arang sekam padi: $2 \mathrm{~kg}$ serbuk gergaji kayu jati). Hal ini ditunjukan dari nilai rata-rata tertinggi untuk diameter batang, yaitu 9,77 dan nilai rata-rata tertinggi untuk jumlah daun, yakni 21. Komposisi media hidroponik yang digunakan pada perlakuan H3 lebih banyak berisi serbuk gergaji. Berdasarkan hasil penelitian ini, penggunaan serbuk gergaji sebagai media tanam sangat baik untuk suatu tanaman, terutama untuk tanaman tomat. Serbuk kayu merupakan bahan organik yang tentunya dalam jangka waktu tertentu akan membusuk dan akan digunakan oleh tanaman sebagai nutrisi untuk pertumbuhan tanaman.

Namun yang perlu diperhatikan bahwa penggunaan serbuk gergaji yang baik sebagai media tanam adalah dari jenis kayu keras dan berdaun lebar. Kayu yang keras banyak mengandung selulosa, sehingga membuat media tanam tidak cepat habis. Kayu yang berasal dari kayu berdaun lebar memiliki komposisi bahan kimia yang lebih baik dibandingkan dengan kayu yang berdaun sempit. Selain itu, kebersihan serbuk gergaji yang digunakan juga diperhatikan. Sementara itu, penggunaan media arang sekam dalam penelitian ini juga memberikan pengaruh yang signifikan terhadap pertumbuhan vegetatif tanaman tomat. Hal ini disebabkan karena karakteristik dari arang sekam yang begitu baik, yakni sirkulasi udara tinggi, kapasitas menahan air tinggi, berwarna kehitaman, sehingga dapat mengabsorbsi sinar matahari dengan efektif. Arang sekam mempunyai sifat yang mudah mengikat air, tidak mudah menggumpal, harganya relatif murah, bahannya mudah didapat, ringan, steril dan mempunyai porositas yang baik. Media arang sekam merupakan media tanam yang praktis digunakan karena tidak perlu disterilisasi, hal ini disebabkan mikroba patogen telah mati selama proses pembakaran. Selain itu, 
arang sekam juga memiliki kandungan karbon (C) yang tinggi sehingga membuat media tanam ini menjadi gembur. Dari beberapa penelitian diketahui juga bahwa kemampuan arang sekam sebagai absorban yang bisa menekan jumlah mikroba patogen dan logam berbahaya dalam pembuatan kompos. Sehingga kompos yang dihasilkan bebas dari penyakit dan zat kimia berbahaya.

Serbuk gergaji dan arang sekam merupakan media tanam yang berasal dari bahan organik yang tentunya dalam jangka waktu tertentu akan membusuk dan akan digunakan oleh tanaman sebagai nutrisi untuk pertumbuhan tanaman itu sendiri. Penggunaan bahan organik sebagai media tanam jauh lebih unggul dibandingkan dengan bahan anorganik. Hal itu dikarenakan bahan organik sudah mampu menyediakan unsur-unsur hara bagi tanaman. Selain itu, bahan organik juga memiliki pori-pori makro dan mikro yang hampir seimbang sehingga sirkulasi udara yang dihasilkan cukup baik serta memiliki daya serap air yang tinggi.

Penggunaan pasir sebagai media tanam dalam penelitian ini dikombinasikan dengan campuran bahan organik yaitu serbuk gergaji dan arang sekam. Oleh karena memiliki pori-pori berukuran besar (pori-pori makro) maka pasir menjadi mudah basah dan cepat kering oleh proses penguapan. Kohesi dan konsistensi (ketahanan terhadap proses pemisahan) pasir sangat kecil sehingga mudah terkikis oleh air atau angin. Dengan demikian, media pasir lebih membutuhkan pengairan dan pemupukan yang lebih intensif. Hal tersebut yang menyebabkan pasir jarang digunakan sebagai media tanam secara tunggal.

Hal yang perlu diperhatikan bahwa, pasir pantai atau semua pasir yang berasal dari daerah yang bersalinitas tinggi merupakan jenis pasir yang harus dihindari untuk digunakan sebagai media tanam, kendati pasir tersebut sudah dicuci terlebih dahulu. Kadar garam yang tinggi pada media tanam dapat menyebabkan tanaman menjadi merana. Selain itu, organ-organ tanaman, seperti akar dan daun, juga memperlihatkan gejala terbakar yang selanjutnya mengakibatkan kematian jaringan (nekrosis).

\section{KESIMPULAN}

1. Tidak terdapat pengaruh komposisi media hidroponik (pasir, arang sekam dan serbuk gergaji) terhadap tinggi tanaman tomat karena nilai $F_{\text {Hitung }}$ perlakuan $(3,72)<\mathrm{F}_{\text {Tabel }}$ $(4,76)$ pada taraf signifikan 5\%. Namun terdapat pengaruh untuk diameter batang dan jumlah daun tanaman tomat, karena untuk diameter batang nilai $\mathrm{F}_{\text {Hitung }}$ perlakuan $(9,48)>F_{\text {Tabel }}(4,76)$ pada taraf signifikan $5 \%$, dan untuk jumlah daun nilai $F_{\text {Hitung }}$ perlakuan $(35,98)>\mathrm{F}_{\text {Tabel }}(4,76)$ pada taraf signifikan 5\%. Dengan demikian, dapat dikatakan bahwa komposisi media hidroponik (pasir kali, arang sekam padi dan serbuk gergaji kayu jati) dapat mempengaruhi pertumbuhan tanaman tomat, dengan perlakuan terbaik berdasarkan hasil penelitian ini adalah 1:1:2 (1 kg untuk pasir kali: $1 \mathrm{~kg}$ untuk arang sekam padi: $2 \mathrm{~kg}$ untuk serbuk gergaji kayu jati). 
2. Besarnya pengaruh komposisi media hidroponik (pasir, arang sekam dan serbuk gergaji) terhadap diameter batang tanaman tomat adalah $2 \%$ dan untuk jumlah daun tanaman tomat adalah $2,1 \%$.

\section{SARAN}

1. Bagi petani yang menanam tomat, disarankan untuk menggunakan media hidroponik (pasir, arang sekam dan serbuk gergaji) sebagai alternatif media tanam dengan komposisinya adalah 1:1:2 (1 takar untuk pasir : 1 takar untuk arang sekam : 2 takar untuk serbuk gergaji). Bisa dicoba juga pada tanaman yang lain.

2. Untuk penulis selanjutnya diharapkan dapat meneliti pengaruh media hidroponik dari beberapa media yang berbeda atau juga pada tanaman yang berbeda.

\section{DAFTAR PUSTAKA}

Agoes. 1994. Jenis Media Tanaman dan Penggunaannya. Penebar Swadaya. Jakarta:

Ashari, Sumeru. 1995. Hortikultura Aspek Budidaya. Universitas Indonesia Press. Jakarta:

Badan Pusat Statistik (BPS). Tanaman Sayuran dan Buah-buahan Semusim Indonesia 2010-2012.

Cahyono, B. 1998. Tomat, Budidaya dan Analisis Usaha Tani. Penebar Swadaya. Jakarta.

Cahyono, B. 1999. Pembudidayaan Tomat dan Cherry. Jakarta: Penebar Swadaya.

Haryoto. 2009. Bertanam Seledri Secara Hidroponik. Kanius. Yogyakarta

Istiyastuti dan T. Yanuharso. 1996. Kultur Hidroponik (Bertanam Tanpa Tanah). Trigenda Karya. Bandung

Kemas Ali Hanafiah, 2010. Rancangan Percobaan Teori dan Aplikasi. PT Raja Grafindo Persada. Jakarta

Pracaya. 1998. Bertanam Tomat. Kanisius. Yogyakarta.

Rihmantoro dan Y. H. Indriani. 1996. Hidroponik Buah Untuk Hobi dan Bisnis. PT. Penebar Swadaya. Jakarta

Sunaryono, H. 2006. Kunci Bercocok Tanam dan Sayur-Sayuran Penting Di Indonesia. Sinar Baru. Jakarta:

Supari. 1999. Tuntunan Membangun Agribisnis. PT Gramedia. Jakarta

Tugiyono, H. 2001. Bertanam Tomat. Penebar Swadaya. Jakarta.

http://Hamisah. 2005. Pengaruh Komposisi dan Pupuk Gandasil D terhadap Pertumbuhan Tanaman Tomat. Diakses pada tanggal 17 Mei 2015.

http://lubisgrafura.wordpress.com/metode-penelitian-kuantitatif. Diakses tanggal $24 \mathrm{Mei}$ 2015.

Wianta, I.K. 1993. Tanaman Hias Rungan. Yogyakarta: Kanisius. Wirganto, B.T.W. 2002. Bertanam Tomat. Agromedia Pustaka. Jakarta 